\title{
Specialevejledning på seks måneder: De nye specialeregler belyst ved erfaringer fra Institut for Statskund- skab, Københavns Universitet
}

\author{
Hanne Nexф Jensen, lektor, Institut for Statskundskab, Kфbenhavns Universitet. \\ Henrik Jensen, professor (MSO), Institut for Statskundskab, Kфbenhavns Universitet.
}

\section{Reviewet artikel}

Artiklen, der bl.a. bygger på resultaterne fra en spørgeskemaundersøgelse blandt specialevejledere på Institut for Statskundskab, KU, viser, at 6månedersreglen har ført til mere fokus på tidsfaktoren i specialevejledningen, men formentlig også ændrede krav til vejlederne. Holdningen til 6månedersreglen hos vejlederne er den samme som hos de studerende, nemlig positiv.

\section{Indledning}

Siden den 1. september 2007 har specialeskrivning været underlagt en bindende tidsbegrænsning på 6 måneder med mulighed for to fortløbende forlængelser på hver 3 måneder. ${ }^{1}$ Studerende og vejleder indgår en formel kontrakt herom.

I artiklen ser vi på 6-månedersreglens mulige effekter på vejledersiden. Vi undersøger følgende spørgsmål, som alle belyser væsentlige sider af forsøget på politisk regulering af tidsforløbet for specialeskrivning: Har 6-månedersreglen påvirket VIP'ernes vejledningspraksis, og dermed hvordan VIP'erne vejleder? Har 6-

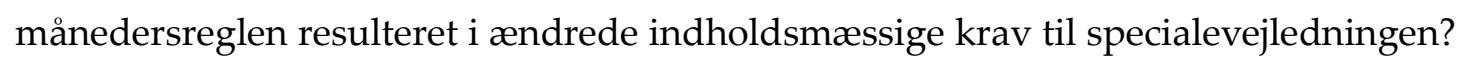
Hvordan ser VIP'erne selv på 6-månedersreglen? Spørgsmålene belyses ud fra erfaringer og data fra Institut for Statskundskab, KU². Hvor det er muligt, sammenligner vi med erfaringer andre steder fra og perspektiverer kort resultaterne ud fra tidsfaktorens forøgede betydning for vejledningen og det tilhørende behov for tidsmæssig styring af vejledningsforløbet. Før spørgsmålene besvares blot nogle få ord om den institutionelle kontekst for specialevejledning og specialeskrivning og om hvordan fænomenet tid og tidsfaktor før er analyseret i vejledningslitteraturen.

\footnotetext{
${ }^{1}$ Bekendtgørelse nr. 864 af 5. juli 2007 om ændring af bekendtgørelse om bachelor- og kandidatuddannelser ved universiteterne (Uddannelsesbekendtgørelsen).

2 Tak til kolleger ved Institut for Statskundskab, der medvirkede i spørgeskemaundersøgelsen, som udgør en vigtig del af artiklens datagrundlag, og til specialeadministrator Mette Cruse Skou, der sørgede for den praktiske gennemførelse af undersøgelsen.
} 


\section{Specialevejledningens og specialeskrivningens typiske kontekst}

Konteksten for specialeskrivning og specialevejledning har vi tidligere præsenteret ved hjælp af en tillempet version af Biggs 3P-model om sammenhænge mellem undervisning og læring (Biggs, 2003, s. 19). ${ }^{3}$ I relation til specialeskrivning handler det om den studerendes og vejleders forudsætninger inden for givne institutionelle rammer. Procesmæssigt fokuserer vi på vejledning, og hvad angår produktet, er det centrale et færdigt speciale skrevet på et halvt år. De elementer, som vi behandler eksplicit i artiklen, er kursiveret i figur 1.

'Tid' som en selvstændig faktor behandles ud fra andre vinkler i vejledningslitteraturen, end vi gør. Eksempelvis har 'tid' været behandlet som studerendes ønsker om mere tid til vejledning (Harboe \& von Müllen, 2006; Rienecker et al., 2005, s. 191f). Her ser vi på 'tid' forstået som tidsfrister, da der i en dansk sammenhæng mangler viden om, hvordan faste afleveringsfrister for specialer virker og bliver opfattet af vejledere og studerende. ${ }^{4}$

\section{Forudsætninger Proces $\quad$ Produkt}

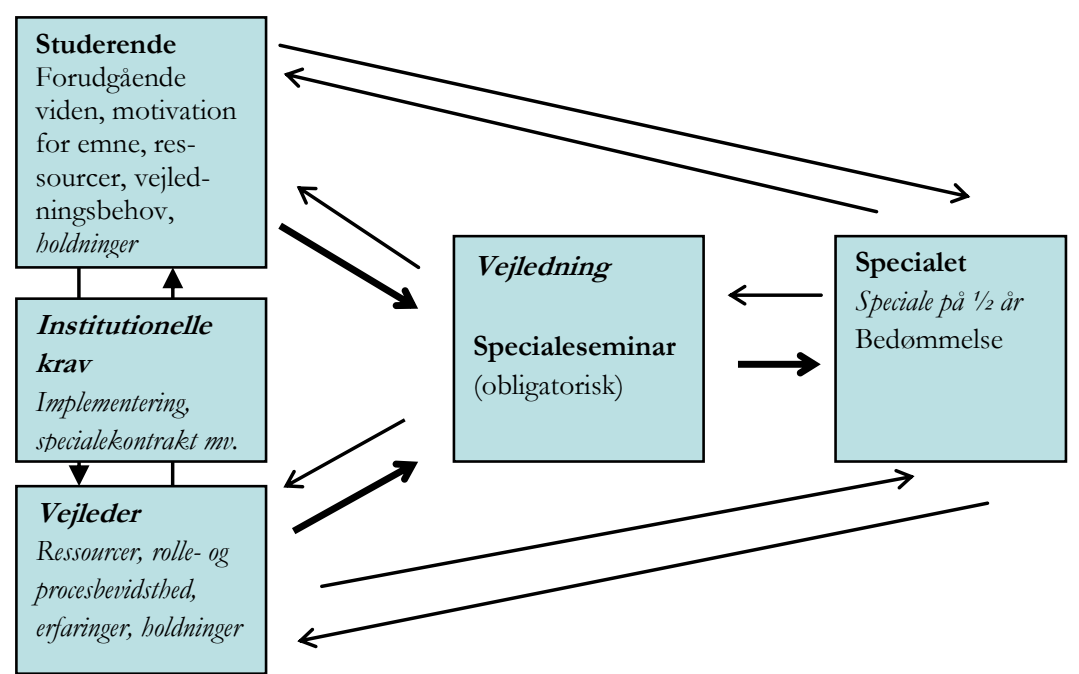

Figur 1. Specialevejledningens typiske kontekst på Institut for Statskundskab, KU (H.N. Jensen videreudvikling af Biggs 2003, p. 19). I artiklen er fokus på de kursiverede elementer.

\footnotetext{
${ }^{3}$ For en uddybning af tillempningen af Biggs 3P-model til specialevejledning se Jensen \& Jensen (2011, s. 26).

${ }^{4}$ Af andre eksempler på behandling af 'tid' er forskelle mellem institutioners og enkeltvejlederes tidsrammer, hvor det anbefales, at det institutionelt bliver fastlagt og synliggjort, hvor megen tid der maksimalt er til vejledning (Rienecker et al., 2005, s. 317f). Andre har fokus på, hvordan den tid, der er til rådighed til vejledning, bruges mest hensigtsmæssigt (Andersen \& Jensen, 2007; Handal \& Lauvås, 2006; Rienecker et al., 2005). Endelig er der pjecer mv. med procesplanlægningsredskaber (Eriksson \& Lilliesköld, 2007; Jørgensen, 2005).
} 


\section{Har 6-månedersreglen haft effekter på VIP'ernes vejledningspraksis?}

For at kunne svare på spørgsmålet er det nødvendigt i et VIP-perspektiv kort at skitsere, hvordan 6-månedersreglen blev gennemført på Institut for Statskundskab, KU. Først blev der på instituttet gjort en solid indsats med at få informeret og diskuteret reglerne med VIP'erne. Specialeskrivning har i mange år været et højprioritetsområde både blandt studerende og VIP'er og fra instituttets side. En del af informationen til og diskussionen med VIP'erne ved indførelsen af 6-månedersreglen angik kravet om afsluttet speciale og om gennemførelsen af den individuelle vejledning på 6 måneder. I forbindelse med instituttets implementering af reglerne var der enighed om at tilpasse det allerede eksisterende koncept for specialeskrivning og vejledning til de nye regler, men ikke lave grundlæggende ændringer. Det eksisterende koncept har hvilet på tre ben, der med de nødvendige tilpasninger blev fastholdt under de nye regler: Dels et introduktionsmøde for nye specialeskrivere, dels et obligatorisk specialeseminar for alle specialeskrivere, dels den individuelle vejledning indrammet af fælles, semestervise tilmeldings- og afleveringsfrister for alle specialeskrivere (jf. Jensen \& Jensen, 2011, s. 26-27).

Her, hvor fokus er på vejledningspraksis, er tre lokale, institutionelle forhold værd at nævne i relation til det tredje ben - den individuelle vejledning: For det første blev det besluttet, at ingen VIP må vejlede specialestuderende uden en underskreven specialekontrakt - 'Ingen kontrakt, ingen vejledning'. Kontrakten, som skal være underskrevet af den studerende og vejlederen i begyndelsen af semestret, indeholder, for det andet, bl.a. følgende formulering af vejlederens forpligtelser: "Jeg er indforstået med, inden for de ressourcemæssige rammer, som instituttet stiller til rådighed, at vejlede på specialet, dvs. efter bedste evne at vejlede og støtte den studerende til at udarbejde et speciale på det bedst mulige faglige niveau. Jeg ... godkender opgaveformulering mv." For det tredje blev mængden af ressourcer og dermed omfanget af vejledningen for første gang formaliseret ved, at vejledningens omfang blev fastlagt $\mathrm{i}$ studieordningen til 25 timers vejledning i løbet af semestret, inkl. forberedelse.

ÆEndrede regler siger i sig selv intet om, hvor vidt specialevejlederne også har ændret praksis. Det har vi derfor undersøgt gennem en spørgeskemaundersøgelse blandt den del af instituttets VIP'er - her kaldet vejledergruppen - der har vejledt specialer både før og efter indførelsen af 6-månedersreglen. Gruppen af VIP'er, 26 i alt, formodedes at have et godt grundlag for lokalt at kunne vurdere effekterne af 6månedersreglen. 
Undersøgelsen blev gennemført i december 2011 ved uddeling af et papirbaseret spørgeskema med syv enkle spørgsmål. ${ }^{5}$ Skemaet kunne besvares anonymt og elektronisk, hvis det ønskedes. Efter et begrænset antal rykkere svarede 24 af 26, hvilket gav en tilfredsstillende svarprocent på 92,3.6

Fremgangsmåden indebar, at der i forhold til vejlederne for nogle spørgsmåls vedkommende var tale om selvrapportering med de svagheder, som det medfører. Mere 'objektive' data findes ikke, eller er vanskelige at fremskaffe. Vejledergruppen fik stillet følgende spørgsmål: "Har indførelsen af 6-månedersfristen fået dig til at ændre praksis for vejledning af specialeskrivere?" Hertil svarede to tredjedele af de 24 respondenter 'Ja', knap en tredjedel 'Nej' og en enkelt svarede 'Ved ikke'.

Gruppen af vejledere, som svarede nej og angav, at de ikke havde ændret praksis, kan ikke nødvendigvis stemples som konservative elementer, der er utilgængelige for forandring eller er ligeglade med nye regler. En nærliggende forklaring på deres svar er, at en del af instituttets VIP'er før indførelsen af 6-måneders reglen i forvejen havde lagt hoveddelen af deres vejledning inden for en halvårsramme. For dem har 6-månedersreglen derfor næppe givet anledning til større justeringer af praksis. Mere interesse knytter sig derfor til de to tredjedele af vejledergruppen, som svarede 'Ja' til at have ændret praksis. De blev bedt om at uddybe deres svar, hvilket alle 16 gjorde.

De uddybende svar lader sig ikke inddele i få enkle kasser, men kan sammenfattes sådan, at den individuelle vejledningspraksis havde ændret sig i lyset af tidsfaktoren, men på forskellig vis. Flere pegede på, at de nu vier afgrænsning eller indsnævring af specialeskrivernes problemstillinger mere opmærksomhed langt tidligere i vejledningsprocessen, end tilfældet var før. Øget bevidsthed om tidsfaktoren kan også spores i andre bemærkninger. For eksempel i svar, der gik på mere fokus på og dialog med den studerende om 'tidsplan' og 'planlægning af specialeforløbet', og

\footnotetext{
${ }^{5}$ Spørgsmålene var følgende med svarmulighederne i parenteser: 1) Har indførelsen af 6-månedersfristen fået dig til at ændre din praksis for vejledning af specialeskrivere (ja/nej/ved ikke)? 1A: Hvis ja, uddyb helst på hvilke punkter, du har ændret vejledningspraksis. 2: Har du bemærket ændringer i de specialeskrivendes valg af emner eller problemstilling som følge af 6-måneders fristen (ja/nej/ved ikke)? 2A: Hvis ja, angiv helst hvordan. 3) Angiv venligst, hvor mange møder du gennemsnitligt mener at have holdt med specialestuderende efter 6-månedersreglens indførelse (færre end 6 møder/6-8 møder/flere end 8 møder)? 4: Hvor enig eller uenig er du i følgende påstand, 'Det er godt, at der er indført en frist for specialet' (helt enig/delvis enig/hverken/eller/delvis uenig/helt uenig/ved ikke)?4A: Eventuelle kommentarer. 5: Hvor enig eller uenig er du i følgende påstand, 'Alt i alt fungerer 6-månedersfristen udmærket på instituttet' (helt enig/delvis enig/hverken/eller/delvis uenig/helt uenig/ved ikke)? 5A: Eventuelle kommentarer. 6: Angiv, om muligt, nogle fordele for dit arbejde som vejleder som følge af indførelsen af 6-måneders-reglen. 7) Angiv, om muligt, nogle ulemper for dit arbejde som vejleder som følge af indførelsen af 6-månedersreglen.

${ }^{6}$ To VIP'er undlod at svare. Det kan skyldes modvilje mod undersøgelsen, hvorfor svarene ikke er repræsentative i forhold til vejledergruppen. Spørgsmål om vejledningspraksis er dog næppe et kontroversielt emne. En indikator herpå er, at kun 4 af 24 VIP'er valgte at svare anonymt.
} 
'mere vægt på færdiggørelsesdatoen' og på, hvad den studerende 'realistisk kan nå på seks måneder'. På linje hermed pegede andre på, at selve vejledningsforløbet er blevet mere 'struktureret', 'fast og formaliseret', 'koordineret', 'målrettet' og 'standardiseret' og enkelte skrev, at de holder flere eller hyppigere møder på kortere tid. I harmoni hermed anførte et par vejledere også, at de var blevet mere 'proaktive', mere 'udfarende' eller var blevet mere 'kontrollerende', hvilket også passer med en øget bevidsthed om tidsfaktoren.

Vi har ikke data på antallet af vejledningsmøder før 6-månedersreglens indførelse, og kan derfor ikke ad den vej understøtte det billede, som her tegnede sig. Der er dog næppe tvivl om, at frekvensen af vejledningsmøder var steget i forhold til tidsrammen, om end det langt fra er al specialevejledning, der kan reduceres til mødeaktivitet, bl.a. fordi vejledning også kan foregå på mail. Knap to tredjedele af vejledergruppen skønnede gennemsnitligt at holde 6-8 vejledningsmøder i et specialeforløb, en tredjedel angav et lavere skøn og et par VIP'er skønnede at holde flere end 8 møder.

Som konklusion kan man sige, at når vejledergruppens egne svar lægges til grund, har 6-månedersreglen har haft effekter på vejledningspraksis hos en betragtelig del af vejlederne. Reglen ser generelt ud til at give sig udslag, om end på forskellig vis, i individuelle vejledningsaktiviteter, der udspringer af en øget bevidsthed om tidsfaktorens betydning.

Konklusionen kan underbygges i tre andre henseender: For det første tilkendegav langt størsteparten af to kuld af instituttets specialestuderende fra foråret $2008 \mathrm{og}$ foråret 2009 på et eksplicit spørgsmål herom i en tidligere undersøgelse, at deres vejleder havde været opmærksom på 6-månedersfristen (Jensen \& Jensen, 2011, s. 29). For det andet var ændringerne i praksis i harmoni med den dominerende holdning i vejledergruppen til 6-månedersreglen, som var helt igennem positiv, hvilket vi vender tilbage til. For det tredje viser en gennemgang af specialeskrivernes individuelle evalueringer af deres specialevejledningsforløb fra foråret 2009 til efteråret 2011 positive tilkendegivelser i forhold til tidsfaktoren. De studerende svarede på et åbent spørgsmål, om hvad der havde været godt ved vejledningsforløbet. Cirka en fjerdel af de i alt 121 evalueringer inddrog tidsfaktoren positivt ved implicit eller eksplicit at rose vejlederen for aktiv projektstyring, fælles tidsplanlægning, aftale møder fra gang til gang og sikre kort tid mellem aflevering af oplæg og efterfølgende vejledning. Desuden roses vejleder også for at have været tilgængelig og fleksibel og svare hurtigt på mails. Evalueringerne var på linje med gængse opfattelser af 'god vejledning', der er vejledning tilpasset den studerendes individuelle behov, og hvor vejleder er tilgængelig, giver konstruktiv feedback og bakker op om deadlines (Rienecker et al., 2005, s. 25f). Der var dog også tidsler i buketten, da cirka en tiendedel efterlyste 
stærkere engagement fra vejlederen i forhold til tidsplanlægning, tilgængelighed og overholdelse af deadlines; men samlet set var de tre nævnte forhold med til at underbygge det dominerende billede af en ændret vejledningspraksis og stærkere bevidsthed om tidsfaktoren hos vejlederne i kølvandet på 6-månedersreglen.

\section{Har 6-månedersreglen indebåret ændrede krav til vejledningens indhold?}

Foruden det forventelige øgede fokus på tidsfaktoren hos vejlederne, kan man spørge, om 6-månedersfristen også indebærer indholdsmæssige ændringer i kravene til vejlederne. Det er tilfældet, hvis de studerende i lyset af tidsfaktoren fravælger eller nedprioriterer bestemte typer af problemstillinger, der kan virke uforenelige med tidsfristen. Derfor blev vejledergruppen også spurgt, om de havde bemærket ændringer i de specialeskrivendes valg af emner eller problemstilling som følge af 6månedersreglen. Hertil svarede to tredjedel 'nej', mens knap en tredjedel svarede ' $j a$ ', og en enkelt svarede 'ved ikke'. Den tredjedel, dvs. syv vejledere, der svarede bekræftende på spørgsmålet, uddybede svaret. Deres kommentarer og iagttagelser gik på, at de studerende oftere end tidligere valgte: 'Smalle emner', 'det lette', 'det, de ved mest om' eller 'uambitiøse, forudsigelige projekter', og at de studerende var tilbøjelige til at fravælge 'spændende og kreative projekter'. Holdbarheden af vurderingerne kan være vanskelig at efterprøve, men den lader sig vurdere på anden vis.

Vi havde nemlig mulighed for at spørge et kuld af specialestuderende fra foråret 2011, om 6-månedersreglen havde påvirket deres valg af problemstilling. Det skete gennem spørgeskemaer uddelt ved undervisningen på instituttets tre specialeseminarer. I alt var 97 specialeskrivere tilmeldt specialeseminarerne og 82 var til stede ved uddelingen af skemaerne og udfyldte dem i forbindelse med undervisningen. Det gav en udmærket svarprocent for populationen på 84,5.7

På spørgsmålet om, hvor vidt 6-månedersfristen havde påvirket deres valg af problemstilling, havde de studerende svarmulighederne 'ja', 'nej' og 'ved ikke'. Næsten 4 ud af 5 (78.0 pct.) svarede, at tidsfristen ikke havde påvirket deres valg af problemstilling. Omvendt svarede knap hver femte studerende (18.3 pct.) 'ja' til, at tidsfristen havde påvirket valg af emne eller problemstilling. 14 ud af 15 specialeskrivere uddybede, på hvilken måde fristen havde påvirket deres emnevalg. Der var tre typer af begrundelser, som dog kan være svære at adskille. Den største gruppe på 9 ud af 14 pegede på faktorer, som knytter sig til de nye vilkår for specialeskrivning, hvor tidsfaktoren får selvstændig betydning. Eksempelvis nævnte nogle, at fristen i sig selv skabte et tidspres, at man for tidligt blev nødt til at lægge sig fast på en problemstil-

\footnotetext{
${ }^{7}$ Det er vanskeligt at se nogen grunde til systematisk skævheder i forhold til de 15 procent af populationen, som ikke har svaret på spørgeskemaerne, da fravær ved en enkelt undervisningsgang næppe influerer på, hvad man vil svare på spørgsmål om 6-måneders reglens indvirkning på valg af problemstilling.
} 
ling, at der kom (for) meget fokus på beskæring af problemstillingen, på afgrænsning af emnet, på tidspunktet for færdiggørelse og på 'om det kan nås'. En mindre gruppe på fire angav direkte at have afstået fra aktiviteter, som de uden 6-månedersfristen ellers ville have udført. For eksempel fik tidsfristen dem til at afstå fra indsamling af tidskrævende data fra mere omfattende litteratursøgning eller fra dataindsamling i udlandet. I et enkelt tilfælde var problemet, at specialets problemstilling var tidsbundet til et empirisk emne, der lå efter fristen for aflevering, nemlig udskrivning af folketingsvalg.

Resultatet på studentersiden flugter godt med, at en tredjedel af vejlederne havde bemærket en ændret adfærd ved valg af problemstilling hos de studerende. Samlet set blev konklusionen, at tidsfristen fik nogle studerende til at fravælge problemstillinger, som var for tidkrævende at analysere, og at vejledere derfor ikke kom til at vejlede på omfattende eller eventuelt 'vilde' specialer i samme omfang som tidligere. ${ }^{8}$ Med Anker Helm Jørgensens metaforer for valg af procesvej, vil der være flere specialeskrivere, der vælger at gå midt på vejen frem for at afsøge grøftekanten eller udforske vildnisset (Jørgensen, 2007, s. 35). ${ }^{9}$ Omvendt var der sandsynligvis tale om et begrænset antal tilfælde, idet 4 af 5 studerende tilkendegav, at 6-månedersreglen ikke påvirkede deres valg af problemstilling.

\section{Hvordan ser VIP'erne på 6-månedersreglen?}

Vender vi os derefter mod vejledernes holdninger til 6-månedersfristen blev vejledergruppen som led i spørgeskemaundersøgelsen bedt om at tilkendegive deres grad af enighed eller uenighed med følgende påstand: "Det er godt, at der er indført en frist for specialet". Af de 24 respondenter erklærerede 22, eller 91.6 pct., sig 'helt enige' eller 'delvis enige', mens to svarede 'hverken/eller'. Ingen tilkendegav uenighed i påstanden. Da det kan være vanskeligt at adskille regelændringen fra instituttets implementering af regelændringen, blev vejledergruppen også præsenteret for følgende påstand: "Alt i alt fungerer 6-månedersfristen udmærket på instituttet". Svarmulighederne og svarmønstrene var de samme: 22 af 24 erklærede sig helt eller delvis enige i påstanden (1 svarede 'hverken/eller' og 1 svarede 'ved ikke'). ${ }^{10}$ Påstanden om, at "Det er godt, at der er indført en frist for specialet" er tilsvarende præsenteret i den før nævnte undersøgelse af 2 kuld af specialeskrivere fra foråret 2008 og 2009 og med et lignende resultat (Jensen \& Jensen, 2011, s. 29). Selv om undersøgelserne af holdninger hos specialeskriverne og specialevejlederne blev gennemført på

\footnotetext{
${ }^{8}$ Det er parallelt med internationale fund. Wisker (2012, s. 43) nævner, at der er færre 'vilde ph.d.projekter', når tidsrammerne får øget fokus.

${ }_{9}^{9}$ Samme tendenser ses i svar fra workshopdeltagere på DUN-konferencen 2012, hvor vores undersøgelse blev præsenteret 29. maj 2012.

${ }^{10}$ Resultatet er på linje med Tine W. Jensen, som på baggrund af interview med 20 vejledere på AU konstaterer, at: "Ingen ønsker de gamle specialeregler tilbage." (Hollesen, 2011).
} 
forskellige tidspunkter, er der udbredt opbakning på både specialeskriver- og specialevejlederside til 6-månedersreglen. Så meget desto mere er der som før nævnt grund til at slutte, at ikke blot de studerende, men også vejlederne har ændret praksis i lyset af reglen.

Vejledergruppens holdninger til 6-månedersreglen kan nuanceres, da gruppen blev bedt om "om muligt, at anføre nogle fordele og ulemper for arbejdet som vejleder som følge af indførelsen af 6-månedersreglen". Det valgte 21 af 24 at gøre. På plussiden anførtes som individuelle fordele, at der var kommet mere sammenhæng i vejledningsforløbet, bedre muligheder for at følge processen og den enkelte studerende, mere fremdrift i vejledningsarbejdet og mere fokuserede og disciplinerede studerende samt bedre mulighed for at planlægge eget arbejde i øvrigt. ${ }^{11}$ På minussiden anførte flere, at der var sket en komprimering af vejledningsarbejdet ved semesterovergange. Det dækker over en ophobning af specialer, der skal bedømmes ved udløbet af et semester samtidig med, at nye specialestuderende skal startes op i det efterfølgende semester. Det blev også nævnt, at der var blevet længere mellem de kreative projekter og mindre fleksibilitet i vejledningen. Enkelte pegede også på en faglig pris i form af, at de ikke kunne stille samme krav som tidligere til omfanget af den studerendes empiriske arbejde, og at man nu skulle være fagligt 'mere pragmatisk' Og ikke uventet pegede nogle vejledere på det medfølgende bureaukrati og kontrol med de studerende i form af kontraktunderskrifter, som er en del af den politiske detailregulering.

\section{6-månedersreglen og dens effekter på vejledningssiden}

Sammenfattende som korte svar på de tre spørgsmål, som vi har stillet indledningsvis, kan man ud fra erfaringerne fra Institut for Statskundskab, KU se, at:

- Størsteparten af specialevejlederne har ændret vejledningspraksis som følge af 6-månedersfristen, idet vejlederne fokuserer mere på vejledningsaktiviteter, der knytter sig til tidsfaktoren.

- Det er også muligt at spore visse, begrænsede ændringer i kravene til vejledningens indhold i retning af mere 'sikre emner' eller omvendt 'færre vilde projekter', om end datagrundlaget er mere usikkert her.

- Vejledergruppens holdninger til 6-månedersreglen er på linje med de studerendes holdninger i deres positive syn på indførelsen af en tidsfrist for specialeskrivning og den måde, hvorpå den fungerer på Institut for Statskundskab, KU.

\footnotetext{
${ }^{11}$ Studerendes øgede 'fokus' på specialet og processen går igen i en rundspørge foretaget blandt vejledere på AU om kontrakters positive virkninger (Hollesen, 2011, s. 5).
} 
Vi har ud fra en tillempet version af Biggs 3P-model om sammenhænge mellem undervisning og læring udpeget den typiske kontekst for specialevejledning og specialeskrivning og tillige fremhævet hvilke forhold, vi har analyseret i relation til 6måneders reglen inden for konteksten. Den politisk betingede 6-månedersregel er en markant ændring i de institutionelle krav, der har sat sig spor i vejledningsprocessens praksisdel (jf. figur 1). Reglen er imidlertid ikke et enkeltstående politisk initiativ. Færdiggørelsestaxametre og øget politisk fokus på hurtigere gennemførelse, senest indføjet i universiteternes udviklingskontrakt underskrevet i juni 2012,12 øger presset på 'vejledning til tiden'. Her er to forhold værd at bemærke. For det første er kandidaternes beskæftigelsessituation et aktuelt eksempel på et forhold, der kan influere på de studerendes specialeskrivnings- og studieadfærd samt motivation og dermed på færdiggørelsestiderne. Det er vilkår, som ikke indfanges af vores variant af Biggs model, men er heller ikke et vilkår, som den enkelte vejleder, universitetsinstitut eller universitetsverdenen som sådan er herre over. For det andet vil både vejledere og studerende, der jo generelt er tilfredse med de faste tidsrammer, være tjent med at blive udstyret med viden og kompetencer, der mere systematisk sætter dem i stand til at håndtere de faste tidsrammer. Det er på linje med en udvikling, hvor behovet for aktivt samarbejde mellem vejleder og studerende om planlægning og tidsstyring har fået mere opmærksomhed (Wisker, 2012, s. 39ff og 392f). Det kan ske i form af erfaringsudveksling mellem vejledere på et institut og via kompetenceudviklingsforløb samt ved eksplicitering af tidsstyring som en kompetence, de studerende skal trænes i tidligere på studiet, for eksempel under BA-projektskrivningen. Der er også grund til fremover at rette opmærksomheden mod praksisorienteret forskning, der kan medvirke til at forbedre planlægning og tidsstyring, som med indførelsen af 6-månedersreglen er blevet en vigtigere del af specialeskrivnings- og vejledningsprocessen.

Hanne Nexø Jensen er lektor ved Institut for Statskundskab. Hun er uddannet cand.adm.pol., ph.d. Var i pædagogikum efter kandidateksamen. Har været studieleder i 5 år og er generel specialevejleder. Hun er mangeårig specialevejleder og har projekter om speciale- og BA-projektvejledning. Forsker derudover i forandringer $i$ og af offentlige organisationer i et kønsperspektiv.

Henrik Jensen er professor (MSO), dr.scient.pol. ved Institut for Statskundskab, Københavns Universitet. Han er uddannet cand.scient.pol., cand.mag. og ph.d. Han har veret studieleder fra 2006 til 2010 og er mangeårig specialevejleder. Hans primære forskningsområde er parlamentsforskning.

\footnotetext{
${ }^{12}$ Ministeriets pressemeddelelse: http://fivu.dk/nyheder/pressemeddelelser/2012/Udviklingskontrakterskal-sikre-bedre-kvalitet-og-hurtigere-gennemfoersel. Se fx KUs Strategiske målplan 2012-14: http://rektorat.ku.dk/strategi/Samlet m lplan- UK.pdf copy/
} 


\section{Referencer}

Andersen, H. L., \& Jensen, T. W. (2007). Specialevejledning - rammer og roller. En universitetspædagogisk undersøgelse. Frederiksberg: Samfundslitteratur.

Biggs, J. (2003). Teaching for Quality Learning at University. What the student does (2nd. ed.). Berkshire: The Society for Research into Higher Education \& Open University Press.

Eriksson, M., \& Lilliesköld, J. (2007). Projektstyring i praksis. København: Forlaget Libris.

Handal, G., \& Lauvås, P. (2006). Forskningsveilederen. Oslo: Cappelen Akademisk.

Harboe, T., \& von Müllen, R. (2006). De studerendes forventninger til specialevejledningen - en spørgeskemaundersøgelse på Det Samfundsvidenskabelige Fakultet og Det Juridiske Fakultet, Københavns Universitet. København: Københavns Universitet, s. 22.

Hollesen, H. (2011). Ud af specialesumpen. I: UNIvers 2011(13), s. 5.

Jensen, H., \& Jensen, H. N. (2011). Specialeskrivning på seks måneder: De nye specialeregler belyst ved erfaringer fra Institut for Statskundskab, Københavns Universitet. I: Dansk Universitetspædagogisk Tidsskrift, 6(10), s. 25-30.

Jørgensen, A. (2005). Færdig til tiden - sådan planlægger og styrer du specialet (2. oplag). Frederiksberg: Forlaget Samfundslitteratur.

Jørgensen, A. H. (2007). Forventninger og ambitioner i skriftlige projekter: Erfaringer omkring to metaforer og en figur. I: Dansk Universitetspædagogisk Tidsskrift(3), s. 33-39.

Rienecker, L., Harboe, T., \& Jørgensen, P. S. (2005). Vejledning - en brugsbog for opgaveog specialevejledere på videregående uddannelser. Frederiksberg:

Samfundslitteratur.

Wisker, G. (2012). The Good Supervisor. Supervising Postgraduate and Undergraduate Research for Doctoral Theses and Dissertations (2nd ed.). Hampshire: Palgrave Macmillan. 